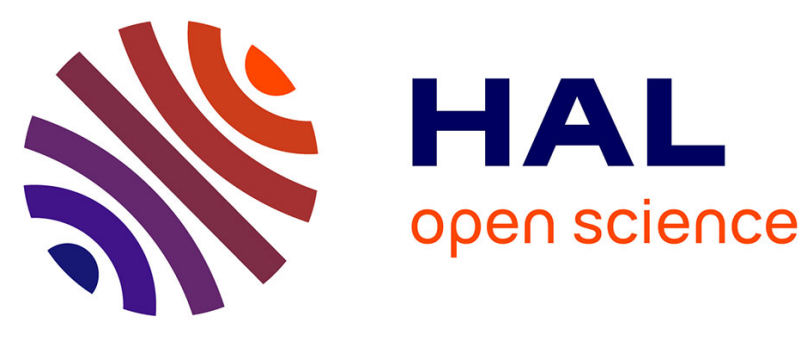

\title{
Endohedral Functionalized Cage as a Tool to Create Frustrated Lewis Pairs
}

Jian Yang, Bastien Chatelet, Véronique Dufaud, Damien Herault, Sabine

Michaud-Chevallier, Vincent Robert, Jean-Pierre Dutasta, Alexandre

Martinez

\section{To cite this version:}

Jian Yang, Bastien Chatelet, Véronique Dufaud, Damien Herault, Sabine Michaud-Chevallier, et al.. Endohedral Functionalized Cage as a Tool to Create Frustrated Lewis Pairs. Angewandte Chemie International Edition, 2018, 57 (43), pp.4212-14215. 10.1002/anie.201808291 . hal-01896309

\section{HAL Id: hal-01896309 https://hal.science/hal-01896309}

Submitted on 6 Apr 2019

HAL is a multi-disciplinary open access archive for the deposit and dissemination of scientific research documents, whether they are published or not. The documents may come from teaching and research institutions in France or abroad, or from public or private research centers.
L'archive ouverte pluridisciplinaire HAL, est destinée au dépôt et à la diffusion de documents scientifiques de niveau recherche, publiés ou non, émanant des établissements d'enseignement et de recherche français ou étrangers, des laboratoires publics ou privés. 


\title{
Endohedral Functionalized Cage as a Tool to Create Frustrated Lewis Pairs
}

\author{
Jian Yang, Bastien Chatelet, Véronique Dufaud, Damien Hérault, Sabine Michaud-Chevallier, \\ Vincent Robert, Jean-Pierre Dutasta, and Alexandre Martinez*
}

\begin{abstract}
A frustrated Lewis pair (FLP) system was obtained by confinement of the Lewis base partner, a Verkade's superbase, in a molecular cavity. Whereas the model superbase lacking cavity displayed no catalytic activity in Morita-BaylisHillman $(\mathrm{MBH})$ reactions, when associated to titanium (IV) chloride, the encaged superbase turns out to be an efficient catalyst under the same conditions. The crucial role of the endohedral functionalized cage on catalytic performance was further demonstrated by the fact that model superbases with bulky substituents were much less efficient to produce active catalysts, as well as by inhibition and substrate selection experiments. ${ }^{31} P$ NMR spectroscopy and mass spectrometry experiments evidenced that no interaction between the Lewis acidic and basic partners occurred when the superbase was capped by a cycloveratrylene (CTV) unit, thus creating a true FLP active system.
\end{abstract}

$M_{\text {olecules possessing a cavity are of great interest, }{ }^{[1]} \text { since }}$ they can be used to stabilize reactive species, ${ }^{[2]}$ or to build nanoreactors presenting a confined catalytic site ${ }^{[3]}$ However, endohedral functionalization of the inner cavity of a molecular capsule is far from trivial, and host molecules presenting true endohedral functionalization of their inner space have been rarely reported and even more seldom used as supramolecular catalyst. ${ }^{[4]}$ We recently reported the synthesis of the hemicryptophane host 1 a incorporating a Verkade's superbase (Figure 1), for which we observed a strong increase of the thermodynamic basicity and a drop in the rate of proton transfer: $\mathbf{1} \mathbf{a}$ is seven times more basic than its counterpart $\mathbf{1 b}$

[*] J. Yang, Dr. B. Chatelet, Dr. D. Hérault, Dr. S. Michaud-Chevallier, Prof. A. Martinez

Aix Marseille Univ, CNRS

Centrale Marseille, iSm2

Marseille (France)

E-mail: alexandre.martinez@centrale-marseille.fr

Dr. V. Dufaud

Laboratoire de Chimie, Catalyse, Polymères, Procédés CNRS

UMR 5265, Université Claude Bernard Lyon 1, CPE Lyon

43 Bd du 11 novembre 1918, 69616, Villeurbanne cedex (France)

Prof. V. Robert

Laboratoire de Chimie Quantique Institut de Chimie

UMR CNRS 7177, Université de Strasbourg

4, rue Blaise Pascal, 67070 Strasbourg (France)

Dr. J.-P. Dutasta

Laboratoire de Chimie, École Normale Supérieure de Lyon

CNRS, UCBL, 46 allée d'Italie, 69364 Lyon (France)

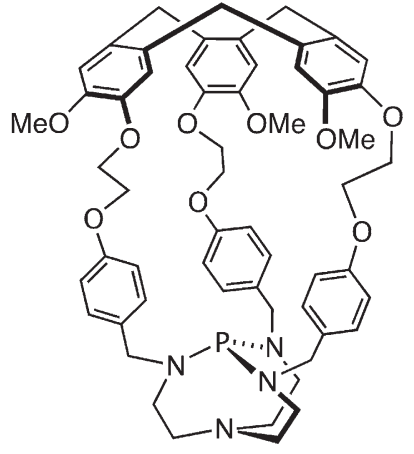

$1 \mathrm{a}$

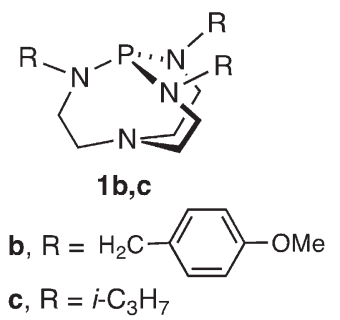

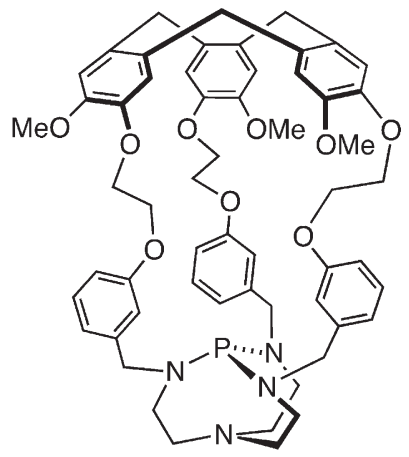

1d

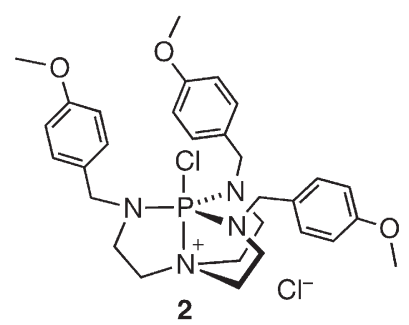

Figure 1. Structures of superbases $1 \mathrm{a}-1 \mathbf{d}$ and chlorinated azaphosphatrane 2 .

without cavity, but its protonation rate is one hundred times slower. $^{[5,6]}$ The X-ray crystal structure of the related Verkade's superbase-hemicryptophane 1d (Figure 1) showed an acetonitrile solvent molecule trapped inside the molecular cavity. Its acidic protons were located in the upper part of the cavity, far from the basic phosphorus, accounting for the low kinetic rate of proton transfer. ${ }^{[6]}$ This system could be viewed as a frustrated Brønsted pair: the specific orientation of the acid partner inside the cavity prevents the acid-base reaction to occur between the entrapped basic phosphorus and the encaged acidic solvent molecule. We thus decided to investigate whether it could be possible to take advantage of this lack of reactivity inside the cavity and extend this behavior to FLP systems within a cage. FLPs, which are systems made of a Lewis base prevented to react with an acidic Lewis counterpart, are of great interest since they can activate small molecules like $\mathrm{H}_{2}$ or $\mathrm{CO}_{2}$, and lead to new and original reactive systems for catalysis. ${ }^{[7,8]}$ We turned our attention to the Morita-Baylis-Hillman $(\mathrm{MBH})$ reaction since the $\alpha$ methylene- $\beta$-hydroxy-carbonyl derivatives obtained by this atom-economical reaction are key intermediates and valuable building blocks in the synthesis of complex natural products and bio-active compounds. ${ }^{[9,10]}$ This reaction is usually catalyzed in the presence of a nucleophilic base, such as amines, or 
phosphines, that can be combined with a transition-metal complex to increase the reaction rate. ${ }^{[1]} \mathrm{J}$. G. Verkade reported previously that proazaphosphatrane sulfides efficiently catalyzed the MBH reaction in the presence of $\mathrm{TiCl}_{4}$ whereas the sulfur-free superbases failed, probably because of phosphorus-titanium interactions (see below). ${ }^{[12]}$ This highlights that the right balance between the Lewis acidic and basic properties of the two partners is necessary in order to avoid the formation of Lewis acid-base adducts and hence, allow the dual activation of both the enone and the aldehyde (see Scheme S1 in the Supporting Information).

Herein, we report on the use of a FLP system for MBH reaction, where the frustrated behavior relates to the confinement of the Lewis base partner in a supramolecular cage structure. Compared to other reported approaches, this strategy proved successful, since the model superbases, even with bulky substituents, either failed to catalyze this reaction or displayed much lower catalytic activity. The key role of the cavity was also evidenced by control and inhibition experiments, DFT calculations and substrate selections.

We first tested the reaction between $p$-chlorobenzaldehyde ( 1 equivalent) and cyclopentenone ( 3 equivalents) with $10 \mathrm{~mol} \%$ of model superbase $\mathbf{1 b}$ as catalyst and one equivalent of $\mathrm{TiCl}_{4}$ relative to the aldehyde, in dichloromethane (DCM) at room temperature. A very low yield, similar to that obtained without superbase, was achieved, showing that the model superbase $\mathbf{1 b}$ displays no catalytic activity under our reaction conditions, as previously reported by J. G. Verkade et al. (Table 1, entries 1 and 2). ${ }^{[12]}{ }^{31} \mathrm{P}$ NMR experiments were performed to investigate if a phosphorustitanium interaction could be responsible for this lack of reactivity (Figures S8-S12). Mixing the model superbase 1b with $\mathrm{TiCl}_{4}$ led to the disappearance of the signal of the free superbase $\mathbf{1 b}$ at $+126.7 \mathrm{ppm}$ and to the appearance of two new peaks (Figures S11, S12): the first one at $-11.9 \mathrm{ppm}$ corresponds to the protonated azaphosphatrane conjugated acid $\mathbf{1 b}-\mathrm{H}^{+}$arising from the traces of $\mathrm{HCl}$ present in $\mathrm{TiCl}_{4}$, and the second signal at $-20.9 \mathrm{ppm}$ is consistent with the formation of the chlorinated azaphosphatrane 2 (Figure 1), which was further confirmed by ${ }^{1} \mathrm{H}$ NMR and mass spectros-

Table 1: The Morita-Baylis-Hillman reaction catalyzed by different systems.

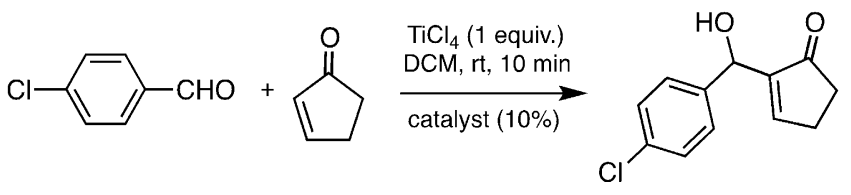

\begin{tabular}{lll}
\hline Entry & Catalyst & Yield [\%] \\
\hline 1 & - & 7 \\
2 & $1 \mathrm{~b}$ & 9 \\
3 & $1 \mathrm{c}$ & 17 \\
4 & $1 \mathrm{a}$ & 48 \\
5 & $1 \mathbf{a}^{-\mathrm{H}^{+} \mathrm{Cl}^{-}}$ & 8 \\
6 & $1 \mathbf{a}^{[\mathrm{a}]}$ & $\mathrm{ND}$ \\
7 & $1 \mathrm{~b}^{[\mathrm{a}]}$ & $\mathrm{ND}$ \\
\hline
\end{tabular}

Reaction conditions: Aldehyde $(0.25 \mathrm{mmol})$, cyclopentenone $(0.75 \mathrm{mmol})$, catalyst $(0.025 \mathrm{mmol}), \mathrm{TiCl}_{4}(0.25 \mathrm{mmol}), \mathrm{DCM}(1.5 \mathrm{~mL})$. [a] Reactions without $\mathrm{TiCl}_{4}$. ND= not detected. copy (Figures S13 and S36 respectively) ${ }^{[13]}$ Besides, 2 was isolated and fully characterized (see the Supporting Information). Thus, the Lewis acid/base partners interact and then react to give $\mathbf{2}$ lacking any nucleophilic properties (Scheme S6). The proazaphosphatrane 1c bearing three isopropyl groups (Figure 1) was recently reported by the group of Krempner to act in combination with bulky boranes as reversed FLP system for hydrogen activation. ${ }^{[14,15]}$ We thus hypothesized that the titanium-phosphorus interaction might be also precluded with this bulky superbase, restoring some catalytic activity. We were pleased to observe that 1 c associated with $\mathrm{TiCl}_{4}$ is able to catalyze this $\mathrm{MBH}$ reaction. However, the improvement of the yield is moderate (Table 1, entry $3,17 \%$ yield), underlining that the extensive steric shielding of the central phosphorus donor by the surrounding isopropyl groups probably only partially isolates these two Lewis acid-base partners. In order to promote more efficiently this FLP behavior, we decided to carry out the $\mathrm{MBH}$ reaction using the encapsulated superbase 1a as catalyst under the above conditions. As shown in Table 1 (entry 4), the association of $\mathbf{1 a}$ with $\mathrm{TiCl}_{4}$ led to the formation of the $\mathrm{MBH}$ product with $48 \%$ yield after only 10 minutes of reaction. This demonstrates that the confined Lewis base, in combination with titanium tetrachloride, acts as an efficient catalyst for this reaction. Control experiments were carried out using the protonated encaged azaphosphatrane $\mathbf{1} \mathbf{a}-\mathrm{H}^{+} \cdot \mathrm{Cl}^{-}$in the presence of $\mathrm{TiCl}_{4}$, and the superbases $\mathbf{1 a}$ and $\mathbf{1 b}$ alone: no catalytic activities were observed in these cases (entries 5-7, Table 1). All these results are consistent with our preliminary studies related to proton transfer, ${ }^{[6 \mathrm{~d}, \mathrm{e}]}$ and suggest that the confined superbase behaves as a FLP and active catalytic system, when associated with $\mathrm{TiCl}_{4}$, whereas the catalytic activity is totally shut down in the case of the model superbase $1 \mathrm{~b}$.

The FLP behavior of the $\mathbf{1 a} / \mathrm{TiCl}_{4}$ catalytic system was further assessed by ${ }^{31} \mathrm{P}$ NMR and mass spectrometry (Figures S14-18 and S37 respectively). Mixing equimolar amounts of $\mathbf{1} \mathbf{a}$ and $\mathrm{TiCl}_{4}$ did not lead to the formation of any detectable $\mathrm{P}-\mathrm{Cl}$ adducts (expected around $-21 \mathrm{ppm}$ in the ${ }^{31} \mathrm{P}$ NMR spectrum, Figures S17, S18), suggesting that the interaction and the subsequent reaction between the two Lewis acid/base partners, are prevented. Thus, these experiments suggest the formation of a FLP between the encaged superbase $\mathbf{1 a}$ and $\mathrm{TiCl}_{4}$ where both the nucleophilicity and the Lewis acidity of the two partners are preserved.

The applicability of this FLP catalyst system was then investigated using two cyclic enones and three differently substituted aldehydes. The catalysis conditions were slightly modified as we observed that using a solution of $\mathrm{TiCl}_{4}$ in DCM instead of pure $\mathrm{TiCl}_{4}$ strongly improved the yields of the reaction: a yield of $75 \%$ is reached for the reaction $p$ chlorobenzaldehyde and cyclopentenone with the $\mathbf{1 a} / \mathrm{TiCl}_{4}$ catalytic system (against $48 \%$ with the previous conditions), whereas the $\mathbf{1 b} / \mathrm{TiCl}_{4}$ catalytic system provides the same yield as the solution of $\mathrm{TiCl}_{4}$ alone $(15 \%)$. As mentioned above, a lower amount of $\mathrm{HCl}$ present in the solution of $\mathrm{TiCl}_{4}$ in DCM, when compared to pure $\mathrm{TiCl}_{4}$, can account for this experimental result. The results are displayed in Table 2 along with those of $\mathbf{1 b}$ and blank control experiments. While the 
Table 2: Comparison of the catalytic activity of $1 \mathrm{a}$ and $\mathbf{1 b}$ with various substrates.

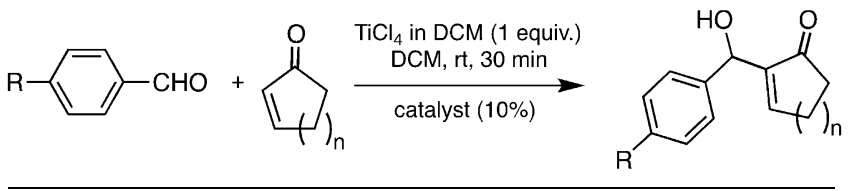

\begin{tabular}{|c|c|c|c|c|c|}
\hline Entry & $\mathrm{R}$ & $n$ & Catalyst & Yield $[\%]^{[a]}$ & $\begin{array}{l}\text { Improvement of } \\
\text { the reaction rate }[\%]^{[b}\end{array}$ \\
\hline 1 & $\mathrm{Cl}$ & 1 & - & 15 & - \\
\hline 2 & $\mathrm{Cl}$ & 1 & $1 \mathrm{~b}$ & 15 & 0 \\
\hline 3 & $\mathrm{Cl}$ & 1 & $1 \mathrm{a}$ & 75 & 400 \\
\hline 4 & $\mathrm{Cl}$ & 2 & - & 7 & - \\
\hline 5 & $\mathrm{Cl}$ & 2 & $1 \mathrm{~b}$ & 8 & 14 \\
\hline 6 & $\mathrm{Cl}$ & 2 & $1 \mathrm{a}$ & 63 & 800 \\
\hline 7 & $\mathrm{NO}_{2}$ & 1 & - & 10 & - \\
\hline 8 & $\mathrm{NO}_{2}$ & 1 & $1 \mathrm{~b}$ & 10 & 0 \\
\hline 9 & $\mathrm{NO}_{2}$ & 1 & $1 \mathrm{a}$ & 55 & 450 \\
\hline 10 & $\mathrm{NO}_{2}$ & 2 & - & 29 & - \\
\hline 11 & $\mathrm{NO}_{2}$ & 2 & $1 \mathrm{~b}$ & 29 & 0 \\
\hline 12 & $\mathrm{NO}_{2}$ & 2 & $1 \mathrm{a}$ & 81 & 179 \\
\hline 13 & $\mathrm{CH}_{3}$ & 1 & - & 11 & - \\
\hline 14 & $\mathrm{CH}_{3}$ & 1 & $1 \mathrm{~b}$ & 11 & 0 \\
\hline 15 & $\mathrm{CH}_{3}$ & 1 & $1 \mathrm{a}$ & 44 & 300 \\
\hline 16 & $\mathrm{CH}_{3}$ & 2 & - & 11 & - \\
\hline 17 & $\mathrm{CH}_{3}$ & 2 & $1 \mathrm{~b}$ & 11 & 0 \\
\hline 18 & $\mathrm{CH}_{3}$ & 2 & $1 \mathrm{a}$ & 48 & 336 \\
\hline 19 & $\mathrm{Cl}$ & 1 & $\mathrm{Et}_{3} \mathrm{~N}$ & 18 & 20 \\
\hline 20 & $\mathrm{Cl}$ & 1 & $1 \mathrm{a}^{[c]}$ & 19 & 27 \\
\hline
\end{tabular}

Reaction conditions: aldehyde $(0.3 \mathrm{mmol})$, enone $(0.9 \mathrm{mmol})$, catalyst (0.03 mmol, $10 \mathrm{~mol} \%), \mathrm{TiCl}_{4}(1 \mathrm{M}$ in DCM, $0.3 \mathrm{mmol}), \mathrm{DCM}(1.0 \mathrm{~mL})$, 30 minutes under an atmosphere of argon. [a] Isolated yield. [b] Defined as $\left(k_{\mathrm{cat}}-k_{\mathrm{TiCl}_{4}}\right) / k_{\mathrm{TiCl}_{4}} \times 100$. [c] The reaction was performed in the presence of $\mathrm{Me}_{4} \mathrm{~N}^{+}$picrate salt (1 equiv relative to $1 \mathrm{a}$ ).

model 1b failed to catalyze these reactions, giving yields similar to those obtained with $\mathrm{TiCl}_{4}$ alone, the encapsulated superbase $\mathbf{1}$ a showed in all cases increased activity (Table 2). To compare more accurately the catalytic activity of the two systems, the improvement of the rate constant of the reaction in the presence of a superbase $(\mathbf{1} \mathbf{a}$ or $\mathbf{1 b})$ with respect to that with $\mathrm{TiCl}_{4}$ alone was calculated $\left(\left(k_{\mathrm{cat}}-k_{\mathrm{TiCl}_{4}}\right) / k_{\mathrm{TiCl}_{4}} \times 100\right.$; Table 2).

Whereas with the model catalyst $\mathbf{1 b}$ no or very little catalytic activity was observed (the improvement of the rate constants ranges from $0 \%$ to $14 \%$ ), the use of the cage catalyst $\mathbf{1 a}$ always led to an improvement of the catalytic activity by a factor of $179 \%$ to $800 \%$ (Table 2). Thus, in each case, the confinement of Verkade's superbase switches its catalytic activity from values close to $0 \%$ to a true synergistic effect with $\mathrm{TiCl}_{4}$ (up to $800 \%$, entry 6, Table 2). The lower gain in activity was obtained for the reaction between cyclohexenone and $p$-nitrobenzaldehyde (179\%, entry 12 , Table 2), probably because, under these conditions, $\mathrm{TiCl}_{4}$ can perform this reaction alone (entry 10, Table 2). Even with the less reactive electron-rich $p$-tolualdehyde and cyclopentenone as substrates, the reaction rate is improved by a factor of $300 \%$ in the presence of $\mathbf{1 a}$ (entry 15, Table 2), whereas the model 1b displays no catalytic activity whatsoever $(0 \%$, entry 14 Table 2). The highest gain in catalytic activity was achieved with $p$-chlorobenzaldehyde and cyclohexenone or cyclopentenone, the reaction rate being enhanced by more than $800 \%$ and $400 \%$ when the catalyst 1 a was present (entries 6 and 3 respectively, Table 2), against $0 \%$ and $14 \%$ with the model superbase $\mathbf{1 b}$.

A series of experiments was then undertaken to demonstrate that the reaction does occur in the confined space of the cage catalyst. First, to rule out the possible contribution of the apical nitrogen in $\mathbf{1 a}$ for some of the catalytic activity observed, the reaction between $p$-chlorobenzaldehyde and cyclopentenone was performed with $\mathrm{Et}_{3} \mathrm{~N}$ instead of the caged catalyst 1a. As shown from Table 2 (compare entries 3 and 19), a dramatic decrease in activity was observed with the improvement of the reaction rate dropping from $400 \%$ to $20 \%$ and a yield close to that obtained with $\mathrm{TiCl}_{4}$ alone (entry 1, Table 2). This suggests that the apical nitrogen of the encaged Verkade's superbase $\mathbf{1}$ a does not take part, at least to a significant extent, in the catalytic process. Our second concern was to assess if the inner space of the cavity was large enough to accommodate the intermediates of the $\mathrm{MBH}$ reaction. The minimized structures obtained by DFT calculations (Scheme S7), showed that both intermediates can be formed inside the molecular cavity. One can see that the most bulky intermediate is partially encapsulated, as previously observed in solution and in the solid state with hemicryptophane complexes of acetylcholine or sugars. ${ }^{[5,16]}$

Further evidence of the crucial role of the endohedral phosphorus site on the reactivity was obtained from inhibition and substrate selection experiments. In the first case, like in enzymatic reaction, the idea was to introduce a suitable nonreactive molecule in the cage. The $\mathrm{Me}_{4} \mathrm{~N}^{+}$cation is well complexed by hemicryptophane hosts because of the cation- $\pi$ interactions between the aromatic rings of the CTV unit and the ammonium guest. $^{[5]}$ The catalytic reaction between 4chlorobenzaldehyde and cyclopentenone was thus carried out in the presence of tetramethyl ammonium picrate (1 equivalent relative to catalyst $\mathbf{1 a}$ ). Under these conditions, the yield dropped to $19 \%$, shutting down the improvement of the reaction rate from $400 \%$ to $27 \%$ (entries 3 and 20, Table 2). The presence of the ammonium cation inside the cage prevents the access of the substrates to the phosphorus active site, hence blocking the reaction. In a second experiment, the bulky enone substrate, 6,6-diphenyl-2-cyclohexen1-one, was synthesized (Scheme S3) and reacted with 4chlorobenzaldehyde in the presence of $\mathbf{1 a}$. In this case no $\mathrm{MBH}$ product could be detected, probably because this bulky compound cannot enter in the cavity of $\mathbf{1 a}$. This substrate size-dependent behavior, mimicking that of enzymes, brings new evidence that the reaction likely takes place inside the molecular cage.

In summary, we have designed a FLP system, where the Lewis base partner is encapsulated in a cage structure. The confinement of the Verkade's superbase in the cavity of a hemicryptophane host prevents the acid-base reaction with the Lewis acidic partner $\left(\mathrm{TiCl}_{4}\right)$ to take place, thus providing an effective system for the $\mathrm{MBH}$ reaction where both partners can act in concert without neutralizing each other. A direct comparison with model—even bulky—superbases, emphasizes the potentiality of such an approach. The key role of the cavity has been highlighted by a set of experiments, bringing 
evidence that the reaction does occur in the confined space of the molecular cavity. The encapsulation of the Verkade's superbase turns its catalytic activity on, allowing some cooperativity with titanium chloride to activate more efficiently the substrate and/or reaction intermediates. Other FLP systems involving the encapsulation of one or the two partners and their use for other organic transformations are now under investigation in our laboratory.

[1] D. J. Cram, M. E. Tanner, Angew. Chem. Int. Ed. Engl. 1991, 30, 1024; Angew. Chem. 1991, 103, 1048

[2] a) R. Warmuth, M. A. Marvel, Angew. Chem. Int. Ed. 2000, 39, 1117; Angew. Chem. 2000, 112, 1168; b) Y. C. Horng, P. S. Huang, C. C. Hsieh, C. H. Kuo, T. S. Kuo, Chem. Commun. 2012, 48 , 8844 ; c) M. Fujita, D. Oguro, M. Miyazawa, H. Oka, K. Yamaguchi, K. Ogura, Nature 1995, 378, 469; d) M. Ziegler, J. L. Brumaghim, K. N. Raymond, Angew. Chem. Int. Ed. 2000 39, 4119; Angew. Chem. 2000, 112, 4285; e) S. K. Körner, F. C. Tucci, D. M. Rudkevich, T. Heinz, J. Rebek, Chem. Eur. J. 2000 6, 187; f) Z. Lin, J. Sun, B. Efremovska, R. Warmuth, Chem. Eur. J. 2012, 18, 12864; g) B. Breiner, K. Rissanen, J. R. Nitschke, Science 2009, 324, 1697.

[3] a) M. Raynal, P. Ballester, A. Vidal-Ferran, P. W. N. M. Van Leeuwen, Chem. Soc. Rev. 2014, 43, 1734; b) C. J. Brown, F. D. Toste, R. G. Bergman, K. N. Raymond, Chem. Rev. 2015, 115, 3012; c) S. H. A. M. Leenders, R. Gramage-Doria, B. de Bruin, J. N. H. Reek, Chem. Soc. Rev. 2015, 44, 433; d) B. Breiner, J. K. Clegg, J. R. Nitschke, Chem. Sci. 2011, 2, 51; e) R. J. Hooley, Nat. Chem. 2016, 8, 202; f) J. K. Sanders, Chem. Eur. J. 1998, 4, 1378 g) Y. Ueda, H. Ito, D. Fujita, M. Fujita, J. Am. Chem. Soc. 2017 139, 6090; h) D. Ajami, J. Rebek, Jr., Acc. Chem. Res. 2013, 46 , 990 ; i) T. C. Lee, E. Kalenius, A. I. Lazar, K. I. Assaf, N. Kuhnert, C. H. CGrun, J. Janis, O. A. Scherman, W. M. Nau, Nat. Chem. 2013, 5, 376; j) M. Juricek, N. L. Strutt, J. C. Barnes, A. M. Butterfield, E. J. Dale, K. K. Baldridge, J. F. Stoddart, J. S. Siegel, Nat. Chem. 2014, 6, 222; k) I. Pochorovski, F. Diederich, Acc. Chem. Res. 2014, 47, 2096; 1) D. S. Kim, J. L. Sessler, Chem. Soc. Rev. 2015, 44, 532.

[4] a) P. Thordarson, E. J. A. Bijsterveld, A. E. Rowan, R. J. M. Nolte, Nature 2003, 424, 915; b) P. Zhang, J. Meijide Suárez, T. Driant, E. Derat, Y. Zhang, M. Ménand, S. Roland, M. Sollogoub, Angew. Chem. Int. Ed. 2017, 56, 10821; Angew. Chem. 2017, 129, 10961; c) Y. Makita, K. Sugimoto, K. Furuyosho, K. Ikeda, S. Jujiwara, T. Shin-ike, A. Ogawa, Inorg. Chem. 2010, 49, 7220; d) S. R. Shenoy, F. R. P. Crisostomo, T. Iwasawa, J. Rebek, Jr., J. Am Chem. Soc. 2008, 130, 5658; e) T. Futagoishi, M. Murata, A. Wakamiya, Y. Murata, Chem. Commun. 2017, 53, 1712; f) A. Galán, E. C. Escudero-Adán, P. Ballester, Chem. Sci. 2017, 8, 7746; g) D. Sechet, Z. Kaya, T.-A. Phan, M. Jouffroy, E. Bentouhami, D. Armspach, D. Matt, L.
Toupet, Chem. Commun. 2017, 53, 11717; h) L. R. Holloway, P. M. Bogie, Y. Lyon, C. Ngai, T. F. Miller, R. R. Julian, R. J. Hooley, J. Am. Chem. Soc. 2018, 140, 8078-8081.

[5] D. Zhang, A. Martinez, J.-P. Dutasta, Chem. Rev. 2017, 117, 4900.

[6] a) J. G. Verkade, P. Kisanga, Tetrahedron 2003, 59, 7819; b) P. Kisanga, J. G. Verkade, R. J. Schwesinger, J. Org. Chem. 2000, 65, 5431; c) M. A. H. Laramay, J. G. Verkade, J. Am. Chem. Soc. 1990, 112, 9421; d) P. Dimitrov Raytchev, A. Martinez, H. Gornitzka, J.-P. Dutasta, J. Am. Chem. Soc. 2011, 133, 2157; e) B. Chatelet, H. Gornitzka, V. Dufaud, E. Jeanneau, J.-P. Dutasta, A. Martinez, J. Am. Chem. Soc. 2013, 135, 18659.

[7] For reviews on FLPs: a) D. W. Stephan, Acc. Chem. Res. 2015, 48, 306; b) D. W. Stephan, G. Erker, Angew. Chem. Int. Ed. 2015, 54, 6400; Angew. Chem. 2015, 127, 6498; c) D. W. Stephan, J. Am. Chem. Soc. 2015, 137, 10018; d) D. W. Stephan, G. Erker, Angew. Chem. Int. Ed. 2010, 49, 46; Angew. Chem. 2010, 122, 50; e) D. W. Stephan, Science 2016, 354, 6317.

[8] Selected examples: a) G. C. Welch, R. R. San Juan, J. D. Masuda, D. W. Stephan, Science 2006, 314, 1124; b) G. C. Welch, D. W. Stephan, J. Am. Chem. Soc. 2007, 129, 1880; c) A. T. Normand, P. Richard, C. Balan, C. G. Daniliuc, G. Kehr, G. Erker, P. Le Gendre, Organometallics 2015, 34, 2000; d) A. Simonneau, R. Turrel, L. Vendier, M. Etienne, Angew. Chem. Int. Ed. 2017, 56, 12268; Angew. Chem. 2017, 129, 12436; e) X. Tao, G. Kehr, C. G. Daniliuc, G. Erker, Angew. Chem. Int. Ed. 2017, 56, 1376; Angew. Chem. 2017, 129, 1396; f) J. Dupré, A. C. Gaumont, S. Lakhdar, Org. Lett. 2017, 19, 694; g) N. Von Wolff, G. Lefèvre, J.-C. Berthet, P. Thuéry, T. Cantat, ACS Catal. 2016, 6, 4526; h) Z. Mo, E. L. Kolychev, A. Rit, J. Campos, H. Niu, S. Aldridge, J. Am. Chem. Soc. 2015, 137, 12227; i) C. P. Sindlinger, F. S. W. Aicher, H. Schubert, L. Wesemann, Angew. Chem. Int. Ed. 2017, 56, 2198; Angew. Chem. 2017, 129, 2232; j) L. Keweloh, H. Klöcker, E.-U. Würthwein, W. Uhl, Angew. Chem. Int. Ed. 2016, 55, 3212; Angew. Chem. 2016, 128, 3266; k) N. Del Rio, M. Lopez-Reyes, A. Baceiredo, N. Saffon-Merceron, D. Lutters, T. Müller, T. Kato, Angew. Chem. Int. Ed. 2017, 56, 1365; Angew. Chem. 2017, 129, 1385; 1) J. Z. Chan, W. Yao, B. T. Hastings, C. K. Lok, M. Wasa, Angew. Chem. Int. Ed. 2016, 55, 13877; Angew. Chem. 2016, 128, 14081; m) Z. Jian, S. Krupski, K. Škoch, G. Kehr, C. G. Daniliuc, I. Císařová, P. Štěpnička, G. Erker, Organometallics 2017, 36, 2940; n) L. E. Longobardi, L. Liu, S. Grimme, D. W. Stephan, J. Am. Chem. Soc. 2016, 138, 2500; o) M. A. Légaré, M. Courtemanche, E. Rochette, F. G. Fontaine, Science 2015, 349, 513; p) T. C. Johnstone, G. N. J. H. Wee, D. W. Stephan, Angew. Chem. Int. Ed. 2018, 57, 5881-5884; Angew. Chem. 2018, 130, 5983-5986.

[9] N.-J. Zhong, Y.-Z. Wang, L. Cheng, D. Wanga, L. Liu, Org. Biomol. Chem. 2018, 16, 5214-5227.

[10] S. Bhowmik, S. Batra, Curr. Org. Chem. 2014, 18, 3078.

[11] Y. Wei, M. Shi, Chem. Rev. 2013, 113, 6659.

[12] J. You, J. Xu, J. G. Verkade, Angew. Chem. Int. Ed. 2003, 42, 5054; Angew. Chem. 2003, 115, 5208.

[13] X.-D. Liu, J. G. Verkade, Inorg. Chem. 1998, 37, 5189.

[14] S. Mummadi, D. K. Unruh, J. Zhao, S. Li, C. Krempner, J. Am. Chem. Soc. 2016, 138, 3286.

[15] S. Mummadi, D. Kenefake, R. Diaz, D. K. Unruh, C. Krempner, Inorg. Chem. 2017, 56, 10748.

[16] Y. Makita, N. Katayama, H.-H. Lee, T. Abe, K. Sogawa, A. Nomoto, S.-I. Fujiwara, A. Ogawa, Tetrahedron Lett. 2016, 57, 5112. 